\title{
PERBANDINGAN KEPUASAN PASIEN TERHADAP PELAYANAN KESEHATAN MENURUT AKSESBILITAS WILAYAH (KASUS KECAMATAN SUNGAI LILIN DAN KECAMATAN TUNGKAL JAYA KABUPATEN MUSI BANYUASIN, SUMATERA SELATAN)
}

\author{
Mirna Taufik ${ }^{1}$, Dewi Haryani Susilastuti², dan Andri Kurniawan ${ }^{3}$
}

Fakultas Geografi, Universitas Gadjah Mada, Yogyakarta Indonesia, ${ }^{1,3}$, Sekolah Pasca Sarjana, Universitas Gadjah Mada, Yogyakarta Indonesia ${ }^{2}$

mirna.taufik@mail.ugm.ac.id

Diterima : Desember 2014 ; Direvisi : April 2015; Dipubikasikan: 30 September 2015

\begin{abstract}
ABSTRAK Sebagai penyelenggara pelayanan publik, pelayanan puskesmas di Kecamatan Sungai Lilin dan Kecamatan Tungkal Jaya selama ini masih banyak dikeluhkan oleh masyarakat. Penelitian ini bertujuan untuk mengetahui kepuasan masyarakat terhadap pelayanan kesehatan di Puskesmas Sungai Lilin dan Puskesmas Tungkal Jaya berdasarkan aksesibilitas wilayah. Penelitian ini menggunakan desain penelitian survei dengan pendekatan kuantitatif deskriptif. Lokasi penelitian di Desa Sungai Lilin dan desa Suka Damai. Pengumpulan data dilakukan dengan wawancara menggunakan kuesioner dan observasi. Secara umum hasil analisis menunjukkan bahwa sebagian besar masyarakat Sungai Lilin dan masyarakat Suka Damai belum puas terhadap pelayanan kesehatan yang di berikan oleh pihak puskesmas. Hal ini terjadi karena tingginya expektasi responden terhadap sebuah pelayanan. Perlu dibuat standar pelayanan puskesmas yang sesuai dengan kemampuan puskesmas, kebutuhan masyarakat dan kondisi lingkungan.
\end{abstract}

Kata kunci: aksesibilitas wilayah; Desa Suka Damai; Desa Sungai Lilin; kepuasan pasien; pelayanan kesehatan.

ABSTRACT As public service providers, health centers at Sungai Lilin and Tungkal Jaya district get complaints from the community. The purpose of the study is to measure level of satisfaction of cesers of community health centers of Sungai Lilin and Tungkal Jaya villages. The study combined guantitative descriptive and analytic approaches with cross sectional design Location of the study at Sungai Lilin and Suka Damai villages. Data were obtained through interview and observation. In general, the analysis shows that most people Sungai Lilin and community Suka Damai not satisfied with the health care that is provided by the clinic. Aspects that are still considered less than satisfactory service responsibility in Sungai Lilin and productivity services in the village Suka Damai. There is a strong negative relationship between service satisfaction with the level of education and income levels and Sungai Lilin Village Suka Damai.

Key words: accessibility region; Suka Damai villages; Sungai Lilin village; patien satisfaction; health services.

\section{PENDAHULUAN}

Pelayanan publik merupakan hal yang mendasar pada masa desentralisasi. Sementara itu, persoalan yang paling mendasar dalam pelayanan publik adalah cara meningkatkan pelayanan publik, terutama pada sektor pendistribusian layanan. Untuk itu, dalam upaya meningkatkan kualitas pelayanan publik, pemerintah harus lebih ketat mengawasi pendistribusian programprogram pelayanan publik. hal ini dimaksudkan agar pelayanan publik lebih mudah diakses, berkelanjutan, dan sesuai dengan harapan masyarakat.

Pemerintah menerapkan banyak jenis pelayanan publik, salah satunya adalah pelayanan publik di bidang kesehatan. Pelayanan publik di bidang kesehatan harus selalu diperhatikan karena kesehatan merupakan salah satu kebutuhan dasar individu dan syarat penting bagi individu untuk dapat beraktivitas secara normal. Dengan kata lain, tingkat urgensi kebutuhan manusia terhadap kesehatan dapat disejajarkan dengan kebutuhan manusia terhadap pangan. Kesehatan sangat penting dalam kehidupan manusia. Oleh karena itu, negara pun konsisten dengan WHO sebagai organisasi kesehatan dunia terkait dengan hak setiap warga negara atas kesehatanya masing-masing. Negara mengeluarkan Undang-Undang Nomor 23 Tahun 1992 tentang Kesehatan untuk menetapkan kesehatan sebagai hak fundamental setiap warga. Sesuai dengan UU No. 23 Tahun 1992, pelayanan kesehatan merupakan salah satu bagian dari pelayanan publik untuk memelihara dan meningkatkan kesehatan yang dilakukan oleh pemerintah dan/atau masyarakat. Oleh karena itu, pelayanan kesehatan merupakan jasa publik yang harus dapat diakses oleh seluruh lapisan masyarakat.

Untuk memenuhi hak-hak warga terhadap kesehatan tersebut, pemerintah perlu menerapkan pelayanan kesehatan yang menyeluruh dan berkelanjutan. Pelayanan dibidang kesehatan merupakan salah satu bentuk pelayanan yang paling banyak dibutuhkan oleh masyarakat. Untuk lebih mengoptimalkan pelayanan kesehatan masyarakat yang berkualitas, pemerintah perlu lebih dulu fokus pada 
program mengedepankan kualitas pelayanan publik yang baik. Melalui Departemen Kesehatan, pemerintah berupaya untuk meningkatkan akses masyarakat pada pelayanan kesehatan yang berkualitas. Sesuai dengan paradigma sehat, Departemen Kesehatan harus mengutamakan upaya kesehatan masyarakat yang dipadukan secara serasi dan seimbang dengan upaya kesehatan perorangan. Departeman Kesehatan memfasilitasi sistem kesehatan dasar dan rujukannya dengan memperluas jaringan yang efektif dan efisien serta peningkatan kualitas pelayanan sesuai standar yang ditetapkan.

Kamus besar Bahasa Indonesia menjelaskan arti akses sebagai jalan masuk dan terusan, sedangkan aksesibilitas adalah hal yang dapat dijadikan jalan masuk, hal yang dapat dikaitkan, dan keterkaitan dua hal. Aksesibilitas sering didefinisikan sebagai jarak dan waktu untuk mengakses pelayanan dengan berbagai modus transportasi, termasuk berjalan kaki, bersepeda maupun berkendaraan umum (Keoning, 1980).

Seperti tercantum dalam Undang-Undang Nomor 32 Tahun 2004 tentang Pemerintah Daerah, maka pemerintah kabupaten/kota berwenang menyelenggarakan pelayanan publik. Dengan demikian, dapat disimpulkan bahwa setiap daerah dituntut selalu berupaya melakukan peningkatan pelayanan kesehatan bagi masyarakatnya. Hal ini bertujuan untuk memberi pelayanan secara lebih merata dan berkualitas kepada seluruh lapisan masyarakat. Sebagai ujung tombak pelayanan kesehatan bagi seluruh lapisan masyarakat, puskesmas harus memiliki mutu pelayanan yang baik, terutama kemudahan akses. Untuk mencapai tujuan tersebut,pemerintah melakukan peningkatan, pemerataan dan perluasan jangkauan pelayanan kesehatan. Namunupaya tersebut belum sepenuhnya dapat memberikan pelayanan kesehatan yang prima. Sampai saat ini masih terus dipertanyakan apakan setiap rumah sakit ataupun puskesmas telah memberikan layanan yang layak atau berkualitas terhadap masyarakat atau hanya sekadar berkewajiban menjalankan program pemerintah. Sering dijumpai puskesmas yang seharusnya mampu memberikan pelayanan optimal bagi masyarakat justru tidak mampu melaksanakan tugasnya dengan baik.

Atas dasar itulah, penelitian tentang kepuasan pasien ini dilakukan. Penelitian ini mengambil di lokasi puskesmas Kecamatan Sungai Lilin dan Puskesmas Kecamatan Tungkal Jaya Kabupaten Musi Banyuasin, Sumatera Selatan. Dua puskesmas terpilih sebagai lokasi penelitian karena memiliki beragam perbedaan aksesibilitas wilayah. Puskesmas Kecamatan Sungai Lilin adalah unit pelayanan kesehatan yang mudah dijangkau oleh masyarakat Kecamatan Sungai Lilin. Sementara itu, Puskesmas Kecamatan Tungkal Jaya yang meskipun terletak di pinggiran jalan lintas, cukup sulit dijangkau oleh sebagian masyarakat karena aksesibilitas wilayahnya masih kurang baik. Untuk mengakses puskesmas, masyarakat harus menggunakan kendaraan pribadi atau meminjam dari kerabat karena tidak ada kendaraan umum yang melintasinya. Di samping itu, kondisi jalan di beberapa desa di Kecamatan Tungkal Jaya juga berbukit-bekit dan berkerikil. Jika terjadi pergantian musim dari musim kemarau menjadi musim penghujan, jalanan tidak dapat difungsikan dengan baik karena sebagian jalan berlumpur dan licin sehingga tidak mungkin dilewati kendaraan.

Penelitian ini mengelaborasi persoalan-persoalan mengenai aksesibilitas yang berhubungan dengan kondisi masyarakat di kecamatan Sungai Lilin dan Kecamatan Tungkal Jaya terhadap akses pelayanan kesehatan, khususnya derajat kemudahan untuk mencapai pelayanan kesehatan. Hal ini sangat perlu dipahami karena akses yang kurang mendukung akan berdampak pada kurangnya masyarakat mendapatkan pelayanan kesehatan. Fenomena inilah yang menjelaskan pentingnya aksesibilitas dalam persoalan akses masyarakat terhadap pelayanan kesehatan.

Pada dasarnya Undang-Undang Nomor 25 Tahun 2009 tentang Pelayanan Publik dirancang dan diselenggarakan untuk mengatasi permasalahan pelayanan publik di Indonesia dan memenuhi kebutuhan masyarakat sebagai pengguna jasa. Namun masih terdapat kesenjangan persepsi antara masyarakat pengguna jasa dan aparat birokrasi mengenai kualitas pelayanan yang diberikan oleh organisasi akan menciptakan suatu penilaian dari masyarakat. Dengan penilaiaan tersebut masyarakat akan mengetahui kualitas pelayanan yang diberikan oleh organisasi publik.

Penelitian berjudul "Perbandingan Kepuasan Pasien Terhadap Pelayanan Kesehatan Menurut Aksesibilitas Wilayah di Kecamatan Sungai Lilin dan Kecamatan Tungkal Jaya" menggunakan indikator indeks pelayanan kesehatan berupa produktivitas, resposivitas, responsibilitas, akuntabilitas, transparansi pelayanan, waktu pelayanan, administrasi pembayaran/pengobatan, dan keramahan dalam pelayanan. Menjadi sangat penting untuk dilakukan karena hasil penelitian tersebut dapat dijadikan sebagai bahan masukan dalam rangka meningkatkan kepuasan masyaralat dalam mendapatkan pelayanan sehingga diharapkan dapat tercipta pelayanan kesehatan yang semakin baik dan berkualitas. 
Penelitian ini bertujuan untuk mengetahui kepuasan masyarakat atau pasien terhadap pelayanan kesehatan di puskesmas menurut aksesibilitas wilayah.Kepuasan pasien adalah tingkat perasaan pasien yang timbul sebagai akibat dari kinerja pelayanan kesehatan. Kepuasan tersebut diperoleh setelah pasien membandingkannya dengan harapannya (Pohan, 2007). Dalam menyelenggarakan layanan, baik kepada pelanggan internal maupun eksternal, pihak penyedia dan pemberi layanan harus selalu berupaya mengacu kepada tujuan utama pelayanan, yaitu kepuasan konsumen (consumer satisfaktion). Tingkat kepuasan yang diperoleh para pelanggan itu biasanya sangat berkaitan erat dengan standar kualitas barang atau jasa yang mereka nikmati (Barata, 2004).

Perilaku masyarakat untuk memanfaatkan pelayanan kesehatan primer yang ada tetap tinggi 6070 persen karena mereka tidak memiliki pilihan lain. Memperoleh obat untuk menyembuhkan sakitnya merupakan faktor yang paling penting dan mendasari pola pengguna pelayanan tersebut (Solikhah, 2008). Pada hakikatnya tingkat kepuasan masyarakat hanya dapat diketahui dari pernyataan masyarakat atau oleh masyarakat yang bersangkutan. Akan tetapi juga masih bersifat subyektif karena tidak akan pernah diketahui apakah pernyataan atau pengakuan dari masyarakat tersebut merupakan pernyataan yang benar-benar tulus atau hanya sekadar basa-basi saja.

\section{METODE PENELITIAN}

Jenis penelitian yang digunakan dalam penelitian ini adalah suatu penelitian yang menggunakan metode survei untuk sampling dan menggunakan metode jenis kuantitatif untuk analisisnya. Populasi dalam penelitian ini adalah seluruh pasien atau masyarakat yang pernah datang berobat dan mendapatkan pelayanan di Puskesmas Sungai Lilin dan Puskesmas Tungka Jaya. Sampel dalam penelitian ini adalahmasyarakat Desa Sungai Lilin dan Desa Suka Damai yang pernah berobat di puskesmas. Adapunkriteria dari sampel adalah pasien yang telah berobat di puskesmas lebih dari sekali, berumur 18 tahun, dapat berkomunikasi dengan baik, dan tidak dalam keadaan terburu-buru. Teknik pengambilan sampel menggunakan cara Purvosive Sampling dengan besar sampel yang dibutuhkan adalah 100 orang menggunakan perhitungan rumus besaran sampel oleh Rahmady (2004) dalam Bungin (2010) sebagai berikut.

$$
\begin{aligned}
& n=\frac{N}{N(d)^{2}+1} \\
& n=\frac{7084}{7084(0,1)^{2}+1}
\end{aligned}
$$

$$
\begin{aligned}
& n=\frac{7084}{71.84} \\
& =98.6
\end{aligned}
$$

Keterangan:

$\mathrm{n}=$ Jumlah sampel yang diinginkan

$\mathrm{N}=$ Ukuran populasi

$\alpha=$ Nilai presesi (sebesar $90 \% \alpha=0,1$ )

Variabel penelitian ada tiga, yaitu variabel independenadalah karakteristik sosial ekonomi, variabel dependen dalam penelitian ini adalah persepsi pelayanan dan kepuasan pasien, sedangkan variabel kontrol adalah aksesibilitas wilayah. Pengukuran persepsi dan kepuasan pasien menggunaka kuesioner dengan total 36 jenis pertanyaan. Sementara itu, analisis data menggunakan analisis deskriptif kuantitatif.

\section{HASIL DAN PEMBAHASAN \\ Karakteristik Responden}

Karakteristik pasien yang datang ke Puskesmas Sungai Lilin dan Puskesmas Tungkal Jaya dapat dilihat pada Tabel 1 di bawah ini. Tampak analisis deskriptif yang dapat mendeskripsikan karakteristik jenis kelamin, umur, pendidikan, pekerjaan, dan pendapatan dari setiap responden.

Tabel 1 berdasarkan jenis kelamin, diketahui bahwa jumlah responden perempuan (64 persen di Sungai Lilin dan 58 persen di Suka Damai) hampir tiga kali lipat responden laki-laki (36 persen di Sungai Lilin dan 42 persen di Suka Damai). Berdasarkan karakteristik jenis kelamin, diketahui bahwa lebih dari 60 persen pengguna puskesmas adalah perempuan dan 42 persen adalah laki-laki. Hal ini terjadi karena perempuan lebih banyak bersentuhan dengan pelayanan puskesmas karena selain untuk kepentingan kesehatan umum, juga berkaitan dengan kesehatan reproduksi serta kesehatan ibu dan anak. Lumenta (1989) memperlihatkan sebuah fenomena bahwa perempuan lebih aktif dalam menanggapi masalah kesehatan dibandingkan dengan laki-laki dan lebih tinggi tuntutannya terhadap pelayanan kesehatan. Perempuan biasanya lebih mudah cemas yang berujung pada ketidakpuasan.

Karakteristik responden berdasarkan umur menunjukkan hal berikut.Responden Sungai Lilin yang berkunjung ke puskesmas mayoritas berusia 30-39 tahun (42 persen) dan responden Suka Damai yang berkunjung ke puskesmas berusia $\geq 50$ Tahun sebanyak (40 persen). Cukup tingginya jumlah warga masyarakat yang berusia lanjut berkunjung ke puskesmas menuntut kepedulian puskesmas untuk memberikan pelayanan kesehatan yang disesuaikan dengan keadaan mereka yang penuh keterbatasan. 
Tabel 1 Distribusi Frekuensi Karakteristik Responden

\begin{tabular}{|c|c|c|c|c|}
\hline \multirow{2}{*}{ Deskripsi } & \multicolumn{2}{|c|}{ Sungai Lilin (Aksesibilitas Tinggi) } & \multicolumn{2}{|c|}{ Suka Damai (Aksesibilitas Rendah) } \\
\hline & Frekuensi & Persentase & Frekuensi & Persentase \\
\hline \multicolumn{5}{|l|}{ Jenis Kelamin } \\
\hline Laki-Laki & 18 & 36 & 21 & 42 \\
\hline Perempuan & 32 & 64 & 29 & 58 \\
\hline \multicolumn{5}{|l|}{ Umur } \\
\hline 18-29 Tahun & 7 & 14 & 4 & 8 \\
\hline 30-39 Tahun & 21 & 42 & 18 & 36 \\
\hline 40-49Tahun & 14 & 28 & 8 & 16 \\
\hline$\geq 50$ Tahun & 8 & 16 & 20 & 40 \\
\hline \multicolumn{5}{|l|}{ Pendidikan Terakhir } \\
\hline SD Kebawah & 15 & 30 & 27 & 54 \\
\hline SLTP & 4 & 8 & 9 & 18 \\
\hline SLTA & 13 & 26 & 10 & 20 \\
\hline D1, D2, D3 & 6 & 12 & 1 & 2 \\
\hline S1 & 12 & 24 & 3 & 6 \\
\hline \multicolumn{5}{|l|}{ Jenis Pekerjaan } \\
\hline Buruh tani & & & 2 & 4 \\
\hline Petani & 1 & 2 & 33 & 66 \\
\hline Pegawaira swasta & 19 & 38 & 3 & 6 \\
\hline Wiraswasta & 30 & 60 & 12 & 24 \\
\hline \multicolumn{5}{|l|}{ Pendapatan } \\
\hline$<650.000$ & & & 1 & 2 \\
\hline 650.000-1 Juta & 2 & 4 & 1 & 2 \\
\hline 1,5 juta- 2 juta & 35 & 70 & 33 & 66 \\
\hline$>2$ juta & 13 & 26 & 15 & 30 \\
\hline
\end{tabular}

Sumber : Olah Data, 2015

Namun jika dilihat dari tingkat pendidikan yang terbanyak adalah SD kebawah, baik di Sungai Lilin maupun di Suka Damai sebanyak 30 persen dan 54 persen. Jika dilihat dari tingkat pendidikan, dapat disimpulkan bahwa lebih dari 50 persen masyarakat Desa Suka Damai yang berpendidikan rendah menggunakan puskesmas sebagai tempat untuk mendapatkan palayanan kesehatan. Pola tingkat pendidikan pengguna puskesmas di Desa Suka Damai ini berbeda dengan pola yang ada di Sungai Lilin. Di Puskesmas Sungai Lilin, sebagian besar pengguna puskesmas justru berpendidikan lebih tinggi, yakni SLTA yang mencapai 26 persen dan perguruan tinggi 24 persen. Dengan memperhatikan tingkat pendidikan masyarakat pengguna puskesmas, prosedur pelayanan di puskesmas harus disesuaikan dan dibuat sesederhana mungkin agar masyarakat yang mempunyai pendidikan rendah tetap dapat menggunakan pelayanan yang diberikan. Pengelola puskesmas juga dituntut lebih aktif menyosialisasikan berbagai layanan atau program yang dilaksanakan oleh puskesmas.

Tabel 1 menjelaskan bahwa sebagian besar responden Sungai Lilin dan Suka Damai memiliki jenis pekerjaan wiraswasta 60 persen dan petani 66 persen. Hal ini menggambarkan bahwa pelayanan puskesmas kurang menarik bagi kelompok masyarakat yang tergolong sibuk atau tidak memiliki banyak waktu luang untuk menunggu antrean pelayanan di puskesmas. Waktu tunggu pelayanan di puskesmas, yang meliputi saat di loket pendaftaran, pemeriksaan, waku menunggu di loket obat ataulaboraturium,relatif lama karena sering terjadi keterlambatan petugas pelayanan ke puskesmas. Hal ini hanya sanggup dipenuhi oleh kelompok masyarakat yang memiliki banyak waktu. Untuk masyarakat yang cukup sibuk dengan rutinitas pekerjaan, menggunakan pelayanan puskesmas cenderung kurang menarik.

Penghasilan responden di bawah upah minimum provinsi (UMP) Rp 1,5 juta-Rp 2 juta per bulan 70 persen untuk responden Sungai Lilin dan 66 persen untuk responden Suka Damai. Dapat disimpulkan bahwa sebagian besar masyarakat pengguna puskesmas berpendapatan sedang. Hal ini menggambarkan bahwa pelayanan puskesmas kurang menarik bagi kelompok masyarakat yang tergolong berpendapatan tinggi. Masyarakat yang berpendapatan tinggi lebih memili melakukan pengobatan di rumah sakit yang ada di pusat kota. Mereka beranggapan bahwa pengobatan yang dilakukan oleh puskesmas tidak semanjur pengobatan yang dilakukan oleh rumah sakit-rumah sakit yang ada di pusat kota. Hal ini mengindikasikan 
bahwa Puskesmas Sungai Lilin dan Puskesmas Tungkal Jaya bukan tempat berobat bagi masyarakat menengah kebawah ataupun masyarakat yang berkecukupan, tetapi menjadi rujukan awal bagi seluruh lapisan masyarakat di wilayah kerja puskesmas.

Tentu saja kualitas pelayanan banyak berpengaruh terhadap minat masyarakat untuk menjadikan puskesmas sebagai tempat rujukan awal untuk mendapatkan pelayanan kesehatan. Oleh karena itu, Puskesmas Sungai Lilin dan Puskesmas Tungkal Jaya terus berupaya sebaik mungkin untuk membenahi berbagai sisi pelayanan demi terciptanya pelayanan yang baik dan memberikan pada kepuasan masyarkat pengguna jasa pelayanan kesehatan.

\section{Deskripsi Persepsi Pelayanan Kesehatan}

Untuk mendapatkan gambaran mengenai persepsi pasien berdasarkan indikator pelayanan di Puskesmas Sungai Lilin dan Puskesmas Tungka Jaya, digunakan kuesioner untuk mengukur persepsi masyarakat terhadap pelayanan kesehatan. Kuesioner terdiri dari empat dimensi pelayanan, yakni produktivitas, responsivitas, responsibilitas, dan akuntabilitas. Untuk lebih jelasnya dapat dilihat pada Tabel 2 .

Jika dilihat dari per indikator pertanyaan, tampak adanya perbedaan persepsi responden mengenai produktivitas pelayanan, baik di Puskesmas Sungai Lilin maupun Puskesmas Tungkal Jaya. Jika dilihat dari skor total persepsi mengenai produktivitas pelayanan, tampak tidak ada perbedaan persepsi responden di kedua puskesmas berdasarkan aksesibilitas wilayah. Pasien atau responden dari kedua puskesmas ini samasama memberikan jawaban tidak setuju yang tinggi terhadap produktivitas pelayanan kesehatan yang diberikan petugas puskesmas. Berdasarkan hasil uji statistik menggunakan uji chi-square nilai $\mathrm{p}=0,469 \geq$ 0,05 yang berarti tidak terdapat perbedaan persepsi antara responden di Desa Sungai Lilin dengan responden Desa Suka Damai. Responden Sungai Lilin dengan aksesibilitas wilayah yang tinggi merasa tidak setuju terhadap produktivitas pelayanan yang ada di Puskesmas Sungai Lilin. Demikian pula halnya dengan responden Suka Damai yang memiliki aksesibilitas rendah merasa tidak setuju dengan produktivitas pelayanan kesehatan yang ada di puskesmas.

Jika dilihat per indikator pertanyaan, maka terdapat perbedaan persepsi terhadap responsivitas pelayanan di puskesmas. Dapat disimpulkan bahwa tidak terdapat perbedaan persepsi pelayanan berdasarkan aksesibilitas wilayah di kedua puskesmas jika dilihat dari skor total persepsi responsivitas pelayanan. Responden di Puskesmas Sungai Lilin dan Puskesmas Tungka Jaya merasa tidak setuju dengan responsivitas pelayanan yang diberikan oleh pihak penyelenggara kesehatan.
Oleh karena itu, diharapkan pihak penyelenggara dapat memperbaiki responsivitas pelayanan yang ada di puskesmas. Berdasarkan hasil uji statistik menggunakan uji chi-square nilai $\mathrm{p}=.999 \geq 0,05$. Dari itu disimpulkan bahwa tidak terdapat perbedaan persepsi responsivitas pelayanan kesehatan antara responden Sungai Lilin yang memiliki aksesibilitas tinggi dengan responden Suka Damai yang memiliki aksesibilitas wilayah yang rendah. Responden Sungai Lilin maupun responden Suka Damai merasa tidak setuju terhadap responsivitas pelayanan kesehatan yang ada di puskesmas. Kedua puskesmas dinilai belum responsif dalam hal memberikan pelayanan.

Berdasarkan skor total persepsi responsibilitas pelayanan, maka dapat disimpulkan bahwa terdapat perbedaan persepsi antarresponden dari kedua puskesmas. Responden di Sungai Lilin cenderung tidak setuju terhadap responsibilitas pelayanan yang ada di puskesmas. Namun responden di Tungkal Jaya cenderung sangat setuju terhadap responsibilitas pelayanan di Puskesmas Tungkal Jaya. Oleh karena itu, diharapkan Puskesmas Sungai Lilin dapat meningkatkan responsibilitas pelayanan di puskesmas agar responden yang menggunakan jasa pelayanan kesehatan di puskesmas merasa puas. Hasil uji statistik menggunakan uji chi-square menghasilkan nilai $\mathrm{p}=$ $0,588 \geq 0,05$. Nilai itu menunjukkan bahwa tidak terdapat perbedaan persepsi yang signifikan antara responden Sungai Lilin yang memiliki aksesibiltas tinggi dengan responden Suka Damai yang memiliki aksesibilitas rendah mengenai responsibilitas pelayanan kesehatan yang ada di puskesmas.

Hasil skor total dari persepsi akuntabilitas, maka dapat disimpulkan bahwa terdapat perbedaan persepsi mengenai akuntabilitas pelayanan kesehatan yang ada di Puskesmas Sungai Lilin dan Puskesmas Tungkal Jaya berdasarkan aksesibilitas wilayah. Responden Puskesmas Sungai Lilin yang memiliki aksesibilitas wilayah yang tinggi tidak setuju dengan akuntabilitas pelayanan yang ada di puskesmas. Namun responden di Puskesmas Tungkal Jaya yang memiliki aksesibilitas wilayah yang rendah merasa sangat puas dengan akuntabilitas pelayanan yang diberikan oleh petugas puskesmas. Dapat terlihat bahwa dengan aksesibilitas yang baik untuk mendapatkan pelayanan kesehatan, responden belum tentu merasa puas terhadap pelayanan yang diberikan pihak puskesmas. Sebaliknya, waupun aksesibilitasnya rendah untuk mendapatkan pelayanan kesehatan, tidak menutup kemungkinan responden akan merasakan puas terhadap pelayanan pihak puskesmas.

Berdasarkan hasil uji statistik menggunakan uji chisquare didapat nilai $\mathrm{p}=0,276 \geq 0,05$. Nilai tersebut 
menunjukkan bahwa tidak terdapat perbedaan persepi antara responden Sungai Lilin yang memiliki aksesibilitas tinggi dengan responden Suka Damai yang memiliki aksesibilitas rendah terhadap akuntabilitas pelayanan kesehatan. Hal ini terjadi karena yang memengaruhi persepsi responden terhadap pelayanan kesehatan adalah tingkat pendidikan dan tingkat pendapatan. Semakin tinggi tingkat pendidikan dan pendapatan responden maka akan semakin tinggi pula tingkat kepuasannya terhadap pelayanan kesehatan.

\section{Hubungan Karakteristik Tingkat Pendidikan Pengguna Layanan Kesehatan dengan Kepuasan}

Hubungan tingkat pendidikan terhadap kepuasan pengguna layanan kesehatan yang ada di Kecamatan Sungai Lilin dan Kecamatan Tungkal Jaya berdasarkan aksesibilitas wilayah dapat dilihat melalui hasil pada Tabel 3. Tabulasi silang antara tingkat pendidikan dengan kepuasan responden terhadap pelayanan kesehatan menghasilkan kesimpulan berikut. Untuk responden Sungai Lilin yang berpendidikan tinggi sebagian besar cenderung merasa tidak puas dengan pelayanan kesehatan 94,7 persen sedangkan yang merasa sangat puas hanya 5,3 persen. Responden yang berpendidikan sedang cenderung merasa puas dengan pelayanan kesehatan karena persentasenya sebesar 58,8 persen dan merasa tidak puas sebanyak 29,4 persen. Untuk responden yang berpendidikan rendah, 64,3 persen cenderung merapa puas dengan pelayanan kesehatan yang diberikan, sedangkan yang merasa tidak puas sebanyak 14,3 persen.

Sementara itu, responden Suka Damai yang berpendidikan tinggi merasa tidak puas dengan pelayanan kesehatan dengan persentase 75 persen. Sebanyak 40 persen responden yang berpendidikan sedang juga merasa puas dengan pelayanan kesehatan yang diterima. Untuk responden yang berpendidikan rendah 52,8 persen merasa sangat puas dan 44,4 persen merasa puas. Hal ini menunjukkan bahwa responden yang berpendidikan rendah cenderung merasa sangat puas terhadap pelayanan kesehatan dibandingkan dengan responden yang berpendidikan tinggi. Ini terjadi pada Puskesmas Kecamatan Sungai Lilin dan Tungkal Jaya. Dapat dikatakan bahwa sebagian besar masyarakat yang ada di Desa Suka Damai Kecamatan Tungkal Jaya yang menggunakan puskesmas sebagai tempat untuk mendapatkan pelayanan kesehatan berpendidikan rendah.

Kuatnya hubungan antarvariabel dinyatakan dalam koefisien korelasi. Seperti halnya output di atas diketahui Correlation (koefisien korelasi) untuk responden Sungai Lilin sebesar -0,634, maka nilai ini menunjukkan hubungan yang tinggi antara tingkat pendidikan dengan tingkat kepuasan masyarakat terhadap pelayanan kesehatan. Oleh karena itu, dapat dikatakan, bahwa semakin rendah tingkat pendidikan responden Sungai Lilin maka akan semakin tinggi tingkat kepuasan responden tersebut terhadap pelayanan kesehatan. Sementara itu, correlation coefficient untuk responden Suka Damai adalah sebesar .330. nilai ini menunjukkan adanya hubungan positif yang rendah antara tingkat pendidikan dengan tingkat kepuasan. Dapat dikatakan bahwa semakin rendah tingkat pendidikan akan semakin tinggi tingkat kepuasan responden Suka Damai.

Tabel 2 Persepsi Responden Mengenai Pelayanan Kesehatan

\begin{tabular}{|c|c|c|c|c|c|c|c|c|c|c|c|c|c|c|}
\hline \multirow[t]{2}{*}{ No } & \multirow[t]{2}{*}{ Skor Total Indikator Pelayanan } & \multicolumn{5}{|c|}{$\begin{array}{c}\text { Sungai Lilin } \\
\text { (Aksesibilitas Tinggi) }\end{array}$} & \multicolumn{5}{|c|}{$\begin{array}{c}\text { Suka Damai } \\
\text { (Aksesibilitas Rendah) }\end{array}$} & \multicolumn{3}{|c|}{ Taraf signifikansi } \\
\hline & & SS & S & $\mathrm{N}$ & TS & STS & SS & S & $\mathrm{N}$ & TS & STS & $\mathrm{X}^{2}$ & df & $\mathrm{P}$ \\
\hline \multirow[t]{2}{*}{1} & Produktivitas & 33 & 103 & 124 & 221 & 119 & 59 & 158 & 145 & 173 & 49 & \multirow{2}{*}{24.880} & \multirow{2}{*}{25} & \multirow{2}{*}{.469} \\
\hline & Persentase & 5,5 & 17,2 & 20,7 & 36,8 & 19,8 & 10,1 & 27 & 24,8 & 29,6 & 8,32 & & & \\
\hline \multirow[t]{2}{*}{2} & Responsivitas & 74 & 88 & 47 & 183 & 57 & 121 & 120 & 66 & 126 & 17 & \multirow{2}{*}{9.360} & \multirow{2}{*}{27} & \multirow{2}{*}{.999} \\
\hline & Persentase & 16,5 & 19,6 & 10,5 & 40,8 & 12,7 & 26,8 & 26,6 & 14,6 & 28 & 3,78 & & & \\
\hline \multirow[t]{2}{*}{3} & Responsibilitas & 28 & 53 & 32 & 119 & 18 & 72 & 62 & 32 & 71 & 13 & \multirow{2}{*}{19.920} & \multirow{2}{*}{22} & \multirow{2}{*}{.588} \\
\hline & Persentase & 11,2 & 21,2 & 12,8 & 47,6 & 7,2 & 28,8 & 24,8 & 12,8 & 28,4 & 5,2 & & & \\
\hline \multirow[t]{2}{*}{4} & Akuntabilitas & 26 & 24 & 9 & 41 & & 31 & 25 & 17 & 26 & 1 & \multirow{2}{*}{15.520} & \multirow{2}{*}{13} & \multirow{2}{*}{.276} \\
\hline & Persentase & 26 & 24 & 9 & 41 & & 31 & 25 & 17 & 26 & 1 & & & \\
\hline
\end{tabular}

Sumber : Olah Data, 2015

Tabel 3. Tingkat Pendidikan terhadap Kepuasan

\begin{tabular}{|c|c|c|c|c|c|c|c|c|c|c|c|c|c|c|c|c|}
\hline \multirow{3}{*}{ Pendidikan } & \multicolumn{8}{|c|}{ Sungai Lilin (Aksesibilitas Tinggi) } & \multicolumn{8}{|c|}{ Suka Damai (Aksesibilitas Rendah) } \\
\hline & \multicolumn{2}{|c|}{ Rendah } & \multicolumn{2}{|c|}{ Sedang } & \multicolumn{2}{|c|}{ Tinggi } & \multicolumn{2}{|c|}{$\Sigma$} & \multicolumn{2}{|c|}{ Rendah } & \multicolumn{2}{|c|}{ Sedang } & \multicolumn{2}{|c|}{ Tinggi } & \multicolumn{2}{|c|}{$\Sigma$} \\
\hline & $\mathrm{n}$ & $\%$ & $\mathrm{n}$ & $\%$ & $\mathrm{n}$ & $\%$ & $\mathrm{n}$ & $\%$ & $\mathrm{n}$ & $\%$ & $\mathrm{n}$ & $\%$ & $\mathrm{~N}$ & $\%$ & $\mathrm{n}$ & $\%$ \\
\hline Tidak Puas & 2 & 14,3 & 5 & 29,4 & 18 & 94,7 & 25 & 50 & 1 & 2,8 & 0 & 0 & 3 & 75 & 4 & 8 \\
\hline Puas & 9 & 64,3 & 10 & 58,8 & 0 & 0 & 19 & 38 & 16 & 44,4 & 6 & 60 & 1 & 25 & 23 & 46 \\
\hline Sangat Puas & 3 & 21,4 & 2 & 11,8 & 1 & 5,3 & 6 & 12 & 19 & 52,8 & 4 & 40 & 0 & 0 & 23 & 46 \\
\hline$\sum \%$ & & 100 & & 100 & & 100 & 50 & 100 & & 100 & & 100 & & 100 & 50 & 100 \\
\hline
\end{tabular}


Sumber : Olah Data, 2015

\section{Hubungan Karakteristik Penghasilan Pengguna Layanan Kesehatan dengan Kepuasan}

Interaksi antara tingkat pendapatan dan tingkat kepuasan masyarakat terhadap layanan kesehatan di Kecamatan Sungai Lilin da Kecamatan Tungkal Jaya berdasarkan aksesibilitas wilayah dapat dilihat melalui tabulasi silang Tabel 4. Tabel tabulasi silang antara tingkat pendapatan dan tingkat kepuasan responden terhadap pelayanan kesehatan menunjukkan hal berikut. Dari 50 responden di Sungai Lilin yang berpendapatan tinggi, 100 persen cenderung merasa tidak puas terhadap pelayanan yang diberikan oleh pihak puskesmas. Kemudian 51,4 persen responden yang berpendapatan sedang cenderung merasa puas dengan pelayanan kesehatan dan 16,2 persen merasa sangat puas.

Sebanyak 80 persen responden Desa Suka Damai yang berpendapatan tinggi cenderung merasa puas dan 20 persen merasa tidak puas. Kemudian 64,7 persen responden yang berpendapatan sedang cenderung merasa sangat puas dengan pelayanan kesehatan, 32,4 persen merasa puas dan 2,9 persen merasa tidak puas terhadap pelayanan yang diberikan. Namun 100 persen responden yang berpendapatan rendah merasa sangat puas terhadap pelayanan kesehatan yang diberikan. Hal ini menunjukkan bahwa berdasarkan tingkat pendapatan, yang merasa sangat puas terhadap pelayanan kesehatan lebih banyak berasal dari Desa Suka Damai dibandingkan dengan Sungai Lilin. Namun responden yang tidak puas terhadap pelayanan kesehatan jika dilihat berdasarkan pendapatannya lebih banyak di Sungai Lilin dibandingkan dengan di Suka Damai.

Hasil koefisien korelasi dapat digunakan untuk mengetahui seberapa kuat hubungan antara variabel tingkat pendapatan dengan tingkat kepuasan. Sesuai dengan koefisien korelasi responden Sungai Lilin didapat sebesar -0,567, sehingga dapat dikatakan variabel tingkat pendapatan dan tingkat kepuasan memiliki hubungan yang kuat meskipun hubungan ini dikatakan sebagai hubungan negatif. Dapat disimpulkan bahwa semakin rendah tingkat pendapatan responden akan semakin tinggi tingkat kepuasannya terhadap sebuah pelayanan kesehatan. Responden Desa Suka Damai jika dilihat dari hasil koefisien korelasinya juga memiliki hubungan yang kuat antarvariabel. Koefisien korelasi responden Suka Damai sebesar 0,622 menunjukkan variabel tingkat pendapatan dan tingkat kepuasan memiliki hubungan positif. Dapat disimpulkan bahwa semakin tinggi tingkat pendapatan akan semakin tinggi tingkat kepuasan. Kepuasan pasien memiliki hubungan dengan biaya yang mereka bayar untuk memperoleh pelayanan kesehatan. Karena kebutuhan terhadap pelayanan kesehatan merupakan kebutuhan yang mutlak, masyarakat rela membayar lebih demi mendapatkan pelayanan yang berkualitas.

\section{Perbedaan Kepuasan Pasien terhadap Pelayanan Kesehatan}

Data tentang perbedaan kepuasan pasien di Puskesmas Sungai Lilin dan Puskesmas Tungkal Jaya dapat dilihat pada Tabel 5. Tabel 5 menggambarkan bahwa dari 50 orang responden di Sungai Lilin,setengahnya 50 persen merasa tidak puas dengan pelayanan kesehatan dan yang merasa puas 19 orang (38 persen). Sementara itu, dari 50 prang responden di Desa Suka Damai, yang merasa tidak puas hanya 4 orang ( 8 persen). Yang merasa puas dengan dengan pelayanan di puskesmas sebesar 46 persen dan yang merasa sangat puas pun 46 persen. Hal ini menunjukkan bahwa pasien yang merasa puas maupun sangat puas terhadap pelayanan kesehatan lebih banyak di Desa Suka Damai dibandingkan dengan di Desa Sungai Lilin meskipun terdapat perbedaan aksesibilitas wilayah.

\begin{tabular}{lcccc}
\hline Kepuasan & $\begin{array}{c}\text { Sungai Lilin } \\
\text { (Aksesibilitas } \\
\text { Tinggi) }\end{array}$ & \multicolumn{3}{c}{$\begin{array}{c}\text { Suka Damai } \\
\text { (Aksesibilitas } \\
\text { Rendah) }\end{array}$} \\
\hline Tidak Puas & 25 & 50 & 4 & 8 \\
Puas & 19 & 38 & 23 & 46 \\
Sangat puas & 6 & 12 & 23 & 46 \\
Total & 50 & 100 & 50 & 100 \\
\hline
\end{tabular}

Tabel 4 Tingkat Pendapatan dan Tingkat Kepuasan

\begin{tabular}{|c|c|c|c|c|c|c|c|c|c|c|c|c|c|c|c|c|}
\hline \multirow{3}{*}{ Pendapatan } & \multicolumn{8}{|c|}{ Sungai Lilin (Aksesibilitas Tinggi) } & \multicolumn{8}{|c|}{ Suka Damai (Aksesibilitas Rendah) } \\
\hline & \multicolumn{2}{|c|}{ Rendah } & \multicolumn{2}{|c|}{ Sedang } & \multicolumn{2}{|c|}{ Tinggi } & \multicolumn{2}{|c|}{$\sum$} & \multicolumn{2}{|c|}{ Rendah } & \multicolumn{2}{|c|}{ Sedang } & \multicolumn{2}{|c|}{ Tinggi } & \multicolumn{2}{|c|}{$\Sigma$} \\
\hline & $\mathrm{n}$ & $\%$ & $\mathrm{n}$ & $\%$ & $\mathrm{n}$ & $\%$ & $\mathrm{n}$ & $\%$ & $\mathrm{n}$ & $\%$ & $\mathrm{n}$ & $\%$ & $\mathrm{n}$ & $\%$ & $\mathrm{n}$ & $\%$ \\
\hline Tidak Puas & - & - & 12 & 32 & 13 & 100 & 25 & 50 & - & - & 1 & 2,9 & 3 & 20 & 4 & 8 \\
\hline Puas & - & - & 19 & 51 & - & - & 19 & 38 & - & - & 11 & 32 & 12 & 80 & 23 & 46 \\
\hline Sangat Puas & - & - & 6 & 16 & - & - & 6 & 12 & 1 & 100 & 22 & 65 & - & - & 23 & 46 \\
\hline$\sum \%$ & - & & & 100 & & 100 & 50 & 100 & & 100 & & 100 & & 100 & 50 & 100 \\
\hline
\end{tabular}

Sumber : Olah Data, 2015 
Aldana, dkk. (2001) mengatakan bahwa faktor yang sangat menentukan kepuasan pasien terhadap pelayanan kesehatan pemerintah adalah perilaku petugas kesehatan terhadap pasien-pasien, terutama yang berkaitan dengan rasa hormat dan sikap sopan petugas. Penelitian Bowers, dkk.(1994) menunjukkan bahwa kepuasan pasien lebih ditentukan oleh hubungan interpersonal dibandingkan dengan kualitas proses dari suatu pelayanan. Blank (1999) juga mengungkapkan bahwa pada umumnya pasien tidak dapat menilai kompetensi teknis sehingga mereka menilai kualitas pelayanan dari karakteristik nonteknis atau hubungan interpersonal dan kenyamanan pelayanan.

Perbandingan kepuasan pasien antara Desa Sungai Lilin dan Desa Suka Damai menurut aksesibilitas wilayah menunjukkan perbedaan yang signifikan. Hasil uji statistik menggunakan uji chi-square menghasilkannilai asymp sig $=0,000(\mathrm{p}<0,05)$. Karena nilai asymp sig lebih kecil dari 0,05, maka hasil uji hipotesisnya dapat ditentukan Ho ditolak dan Ha. Ini berarti ada perbedaan kepuasan pasien terhadap pelayanan kesehatan menurut aksesibilitas wilayah.

Kepuasan Pasien menurut Tingkat Pendidikan, dan Tingkat Pendapatan dengan Variabel Kontrol

Hasil penelitian ini mengungkapkan dua hal yang sangat penting. Pertama bahwa masyarakat pengguna layanan kesehatan di Puskesmas Sungai Lilin dengan tingkat pendidikan tinggi masih kurang puas atau tidak puas dengan pelayanan yang diberikan oleh pihak puskesmas. Kedua, terdapat tuntutan terhadap penyediaan layanan kesehatan yang lebih berkualitas dibandingkan dengan pelayanan yang diberikan sekarang.Tampak bahwa masyarakat menurut adanya peningkatan pelayanan yang lebih berkualitas. Oleh karena itu, seharusnya pemerintah daerah, khususnya Dinas Kesehatan selaku instansi yang bertanggung jawab, mengambil kebijakan dan tindakan yang tepat untuk perbaikan pelayanan. Hal ini dimaksudkan untuk memberikan pelayanan yang terbaik kepada masyarakat, terlebih lagi kepada masyarakat yang banyak mengerti tentang pelayanan kesehatan.

Tingkat kepuasan responden Suka Damai dengan tingkat pendidikan berdasarkan aksesibilitas wilayahmenunjukkan bahwa terdapat perbedaan tingkat kepuasan.Hal ini menunjukkan bahwa aksesibilitas wilayah bukan salah satu faktor yang berpengaruh pada tingkat kepuasan terhadap pelayanan kesehatan, baik di Sungai Lilin maupun di Suka Damai. Jika kepuasan pasien dilihat dari tinggi rendahnya tingkat pendidikan, dapat dikatakan bahwa semakin tinggi tingkat pendidikan akan semakin rendah tingkat kepuasan dan semakin rendah tingkat pendidikan akan semakin tinggi tingkat kepuasan. Menurut Depkes (1990), tingkat pendidikan memengaruhi persepsi seseorang karena tingkat pendidikan menentukan cara berpikir seseorang dalam menghadapi segala. Semakin tinggi tingkat pendidikan seseorang, maka semakin kritis orang tersebut dalam menilai pelayanan yang diterimanya. Dampaknya adalah orang dengan pendidikan tinggi tersebut akan sulit mereka puas pada pelayanan tersebut.

Responden yang berpendapatan tinggi dan memiliki aksesibilitas wilayah yang tinggi cenderung merasa tidak puas terhadap pelayanan di puskesmas. Berbeda halnya dengan responden yang berpendapatan sedang, mereka cenderung merasa puas terhadap pelayanan yang diberikan. Responden dengan pendapatan tinggi cenderung lebih menuntut ketersediaan pelayanan kesehatan di puskesmas. Dengan pendapatan yang tinggi, mereka dapat memilih tempat pelayanan kesehatan yang menurut mereka dapat memberikan pelayanan yang lebih berkualitas. Oleh karenanya, puskesmas hanya dijadikan sebagai tempat rujukan awal untuk mendapatkan tempat pelayanan yang diingikan.

Responden Desa Suka Damai dengan aksesibilitas rendah (jalan tidak beraspal dan berlubang) dengan pendapatan rendah (100 persen) merasa sangat puas terhadap pelayanan kesehatan yang diperoleh. Kemudian 64,7 persen responden dengan tingkat pendapatan sedang cenderung merasa sangat puas terhadap pelayanan yang diberikan meskipun dengan aksesibilitas wilayah yang rendah. Sebanyak 80 persen responden dengan tingkat pendapatan tinggi merasa puas terhadap pelayanan kesehatan. Meskipun responden Desa Suka Damai memiliki aksesibilitas wilayah yang rendah, seperti jalanan yang tidak beraspal dan berlubang, jarak yang jauh, dan keterbatasan kendaraan untuk mencapai pelayanan kesehatan, mereka tetap merasa puas terhadap pelayanan di puskesmas. Hal ini terjadi karena hampir sebagian besar responden Desa Suka Damai, baik yang berpendapatan rendah maupun tinggi, masih lebih memercayai dukun dibandingkan dengan tenaga medis. Ketika melakukan pengobatan pada tenaga medis, seperti di puskesmas, mereka telah terbiasa terhadap perlakuan tenaga medis kepada mereka, yang sedikit tidak sopan, bersuara keras, dan tidak ramah.

\section{KESIMPULAN}

Secara umum terdapat perbedaan tingkat kepuasan pasien yang signifikan antara pasien Puskesmas Sungai Lilin dengan pasien Puskesmas Tungkal Jaya. Akan tetapi, perbedaan tingkat kepuasan pasien bukan berdasarkan aksesibilitas wilayah. Perbedaan tingkat 
kepuasan pasien berasal dari tinggi rendahnya tingkat pendidikan dan juga tingkat pendapatan responden.Hasil uji korelasi menunjukkan adanya hubungan antara tingkat kepuasan dengan tingkat pendidikan dan juga terdapat hubungan antara tingkat kepuasan dengan pendapatan responden berdasarkan aksesibilitas wilayah. Semakin tinggi tingkat pendidikan seseorang, akan semakin kritis orang menilai pelayanan yang diberikan. Dampaknya adalah orang dengan pendidikan tinggi akan sulit puas terhadap pelayanan yang diberikan. Berdasarkan tingkat pendapatan, responden dengan pendapatan tinggi cenderung lebih menuntut ketersediaan pelayanan kesehatan di puskesmas. Dengan pendapatan yang tinggi, mereka dapat memilih tempat pelayanan kesehatan yang menurut mereka dapat memberikan pelayanan yang lebih berkualitas.

\section{DAFTAR PUSTAKA}

Aldana, J.M., Piechulek, H. \& Al-Shibir, A. (2001). Client Satisfaction and Quality of Health Care in Rural Bangladesh. Bulletin of the World Health Organization.

Barata, A.A. (2004). Dasar-Dasar Pelayanan Prima. Jakarta. Gramedia.
Bowers, M.S., Swan, J.E., \& Koehlor, W.F. (1994). What Attribute Determine Quality and Satisfaction with Health Care Delivery. Health Care Management Review. Aspen Publisher, Inc. Maryland.

Departemen Kesehatan RI. 1990. Peraturan Mentri Kesehatan RI No 416/ Menkes / Per / IX / 1990. Jakarta.

Koening J. G. (1980). Indication of urban accessibility: Theory and application. Transportation Journal. 9(2), Doi: 10.1007/BF00167128.

Lumenta, B. (1989). Pasien, citra, Peran, dan Perilaku. Yogyakarta. Penerbit Kanisius.

Pohan, I.S. (2007). Jaminan mutu layanan kesehatan dasar-dasar pengertian dan penerangan. Jakarta. Buku Kedokteran EGC.

Republik Indonesi. (1992). Undang-Undang Nomor 23 Tahun 1992 tentang Kesehatan. Jakarta.

Solikha. (2008). "Hubungan Kepuasan Pasien dengan Minat Pasien dalam Pemanfaatan Ulang Pelayanan Pengobatan"Jurnal Manajemen Pelayanan Kesehatan, volume II Nomor. 04 Desember. Yogyakarta. PMPK Fakultas Kedokteran Gadjah Mada. 